\title{
“Comparative Study of Soil Mixed vermicompost and Cattle Dung on the Growth Parameters of Triticum astivum (Wheat) and Faciolus mungo (Urad) Plant"
}

\author{
Bhati Praveesh ${ }^{1}$, Shouche Shobha ${ }^{2}$, Jain Sudhir Kumar ${ }^{3}$, Dhundhale Kavita ${ }^{4}$ \\ ${ }^{1}$ Former Assit. Professor, Advance College, Ujjain (M.P.), bhati_p212@yahoo.co.in \\ ${ }^{2}$ Assit. Professor, Govt.Madhav Science PG College, Ujjain (M.P.), shobha.shouche@gmail.com \\ ${ }^{3}$ Reader, SOS in Microbiology, VikramUniversity,Ujjain (M.P.), sudhirkjain1@rediffmail.com \\ ${ }^{4}$ Research Scholar, Holkar Science College, Indore (M.P.), kavitajnv01@gmail.com
}

Received Date: May 1, 2017

Accepted Date: May 31, 2017

Published Date: July 31, 2017

Abstract: The application of vermicompost to improve the physical properties of soils is a promising technology to meet the requirements of high plant growth and cost-effective recovery. Therefore, the aim of this study was to investigate the comparative effect of different proportion of vermicompost and cattle dung mixed soil on Triticum astivum (Wheat) and Faciolus mungo (Urad) Plant. Different growth parameters viz. germination studies, plant length, dry weight and photosynthetic pigment were analyzed. In the present investigation highest germination percentage, plant length,dry weight of root /shoot and chlorophyll-carotenoid percentage were recorded in $50 \%$ soil treated with vermicompost and cattle dung than control soil and other proportions. It has also found that all the selected growth parameters of both Wheat and Urad plant showed significant improvement in vermicompost treated soil than cattle dung treated soil. The present investigation clearly revealed that the addition of vermicompost to soil greatly enhanced the yield in Wheat and Urad plant.

Keywords: Vermicompost, cattle dung compost, chlorophyll, dry weight, germination.

\section{INTRODUCTION}

The quality of the soil is an imperative factor to yields in crop farming and therefore the practice of applying organic manure to maintain soil fertility is a key prerequisite to sustain and eminence crop production. With the increase in world population and the on-going need for fertilisers to produce food crops, organic manure offers an alternative fertiliser to fulfil the requirements of elements. Although India could achieve self-sufficiency in agriculture by an increased use of chemical fertilizers but it also deteriorates soil health and causes eco-pollution (Joshi, et.al.2013).The adoption of organic farming practices not only declining the risk of soil spoiling but also increase global productivity and environment protection (Waniet et.al.,2002). Organic fertilizer has greater advantage over chemicals therefore it has more realized (Mathivanan, 2012). There are so many types of organic wastes viz. animal dung, urban waste, municipal solid waste etc. recognized as a raw material for preparation of compost and use for agriculture practice. With the help of composting process not only the problems of waste is eliminated but it is also used as a complete nutrients source for plant growth (Hoitink, 1993). Traditional composting of cattle dung wastes has been known for many years for but new methods of composting i.e. vermicomposting have become much more popular and significant due to their high nutrients value then simple composting. 
"Comparative Study of Soil Mixed vermicompost and Cattle Dung on the Growth Parameters of Triticum astivum (Wheat) and Faciolus mungo (Urad) Plant"

Vermicompost is a finished goods that formed by microbial-earthworm interaction. (Edwards and Burrows, 1988).By that interaction organic compound is turn in to small absorbable component (Aira et al., 2000). The use of vermicompost alone or in combination with other bio-fertilizers have been proved by several investigators and found growth and yield of various crops like Urad and Soyabean (Javed and Panwar, 2013), Setaria grass (Sabrina et al. 2013), Lilies (Mirakalaeie et al. 2013), Marigold (Paul and Bhattacharya 2012), Groundnut (Mycinet al. 2010), Okra (Ansari and Kumar Sukhraj 2010), Cucumber (Azarmi et al. 2009), Tomato (Lazcano et. al. 2009), Amaranthus sp. (Uma and Malathi 2009), Garlic (Suthar 2009), Strawberry (Singh et al. 2008), Spinach (Peyvast et. al. 2008), Maize (Gutie'rrez-Miceli et al. 2008), Sorghum (Hameeda et al. 2007), Potato (Alam et al. 2007), Radish (Bucker field et.al.1999), Grape (Buckerfield and Webster,1998) Garden cress (Maseiandro et.al. 1997),Onion (Thanunathan, 1997) , Vanila (Siddagan gaiah et.al. 1996)Cloves and Black Peppers (Thankamani et.al.1996), Cardamom (Vadiraj et.al.1993), Tomato and Peppers (Wilson and Carlile, 1989), Soyabean (Chan and Griffith, 1988), Junipers (Scott,1988), Wheat and Cabbage (Edwards and Burrows, 1988). The present investigation was designed to keeping in view that organic fertilizer could be substitute of chemical fertilizer.

\section{Materials And Methods}

\section{Seed Materials}

Wheat (Triticum astivum) and Urad (Faciolus mungo) seeds were collect from Agriculture Regional Research Centre, Kothi Road, Ujjain(M.P.)India.

\section{Vermicompost}

Vermicompost was obtained from Govt. Madhav Science College, Ujjain (M.P.) India.

\section{Soil}

Fertilizer free soil was collected from the field near Advance College, Ujjain. It was thoroughly washed by distilled water to remove chemicals.

\section{Cattle dung}

Urine free cattle dung was collected in large-sized rectangular plastic container from cattle house of Ujjain city (Suthar and Singh, 2008).

Experiment was conducted in duplicate sets with different proportions of soil-vermicompost and soil-cattle dung mixture mentioned in table no.1.These mixtures were seeded by Triticum astivum(Wheat) and Faciolus mungo(Urad) in a plastic pot (Fig,no.1\&2).Sets were kept under optimum condition for plant growth. Adequate moisture was maintained by addition of distilled water. The effects of soil mixed vermicompost and cattle dung on the growth of plants were measured by following criteria.

Table 1. Different proportion of vermicompost and cattle dung with soil

\begin{tabular}{|c|c|c|c|c|}
\hline \multirow{2}{*}{$\begin{array}{c}\text { Composition } \\
\text { (Total 800gm) }\end{array}$} & \multicolumn{2}{|c|}{ Vermicompost treated soil } & \multicolumn{2}{c|}{ Cattle dung treated soil } \\
\cline { 2 - 5 } & Vermicompost & Soil & Cattle dung & Soil \\
\hline Control A & $800 \mathrm{gm}$ & ---- & $800 \mathrm{gm}$ & ---- \\
\hline $\mathbf{7 5 \%}$ & $600 \mathrm{gm}$ & $200 \mathrm{gm}$ & $600 \mathrm{gm}$ & $200 \mathrm{gm}$ \\
\hline $\mathbf{5 0 \%}$ & $400 \mathrm{gm}$ & $400 \mathrm{gm}$ & $400 \mathrm{gm}$ & $400 \mathrm{gm}$ \\
\hline $\mathbf{2 5 \%}$ & $200 \mathrm{gm}$ & $600 \mathrm{gm}$ & $200 \mathrm{gm}$ & $600 \mathrm{gm}$ \\
\hline
\end{tabular}


“Comparative Study of Soil Mixed vermicompost and Cattle Dung on the Growth Parameters of Triticum astivum (Wheat) and Faciolus mungo (Urad) Plant"

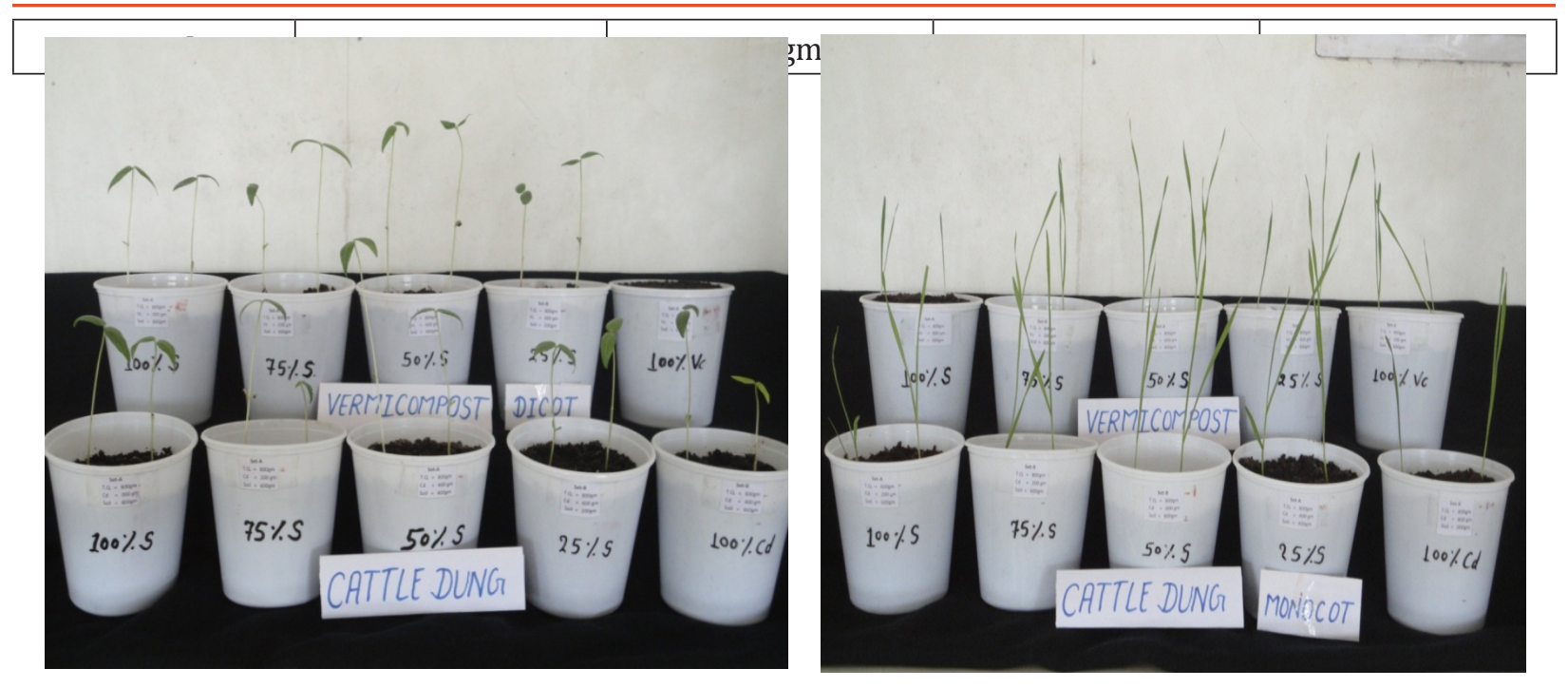

Fig 1. Experiment setup of Urad plant

Fig 2. Experiment setup of Wheat plant

\section{Germination study}

Germination study was conducted in the pots filled with soil mixed with different doses of Vermicompost and cattle dung. The result was measured on the basis of arising of germinating filaments from seeds.

\section{Length of plant}

The length of 14 days old Wheat and Urad plants were measured by using a scale and the values were recorded in centimeter.

\section{Dry weight of root and shoot}

The same plants used for root and shoot growth measurement. They were kept in a hot air oven at $105^{\circ} \mathrm{C}$ for 24 hrs. and dry weight taken by using an electrical single pan balance. The values of dry weight were expressed in g/root or shoot.

\section{Chlorophyll}

Leaf of Wheat and Urad plant were estimated for total chlorophyll. One gm. of fresh leaf was crushed, mixed with $10 \mathrm{ml}(80 \%)$ acetone and centrifuged at $800 \mathrm{rpm}$ for 15 minutes. The supernatant was separated and the residue was again re-extracted with $10 \mathrm{ml}$ (80 \%) acetone. Supernatant was diluted and their absorbance values were taken at 645 and $663 \mathrm{~nm}$ in a UV-Spectrophotometer (Arnon, 1949).The concentration of chlorophyll was quantified by following formula.

$$
\begin{gathered}
\text { Chlorophyll } \mathrm{a}=[(12.7 \mathrm{X} \text { OD at 663) }-(2.69 \mathrm{X} \text { OD at } 645)] \mathrm{X} \text { dilution factor } \\
\text { Chlorophyll } \mathrm{b}=[(22.9 \mathrm{X} \text { OD at } 645)-(4.68 \mathrm{X} \text { OD at } 663)] \mathrm{X} \text { dilution factor } \\
\text { Total chlorophyll }=[(20.2 \mathrm{X} \text { OD at } 645)-(8.02 \mathrm{X} \text { OD at } 663)] \mathrm{X} \text { dilution factor. }
\end{gathered}
$$


“Comparative Study of Soil Mixed vermicompost and Cattle Dung on the Growth Parameters of Triticum astivum (Wheat) and Faciolus mungo (Urad) Plant"

\section{Carotenoid}

For carotenoid estimation, the absorbance values of the same plant extract was taken at $480 \mathrm{~nm}$ in a UV spectrophotometer (Arnon,1949). The concentration of carotenoid was quantified by following formula.

$$
\text { (1000- } \mathrm{A}_{470} \text { ) - } 1.90 \text { X (Chlor.A-63.14) X (Chlor. B) X2/14 }
$$

\section{RESULTS}

\section{Germination study}

Germination percentages of the seed are influenced by the application of various doses of Vermicompost and cattle dung. The highest germination percentage (100\%) was recorded in Wheat and Urad seed grown with of $50 \%$ of vermicompost and cattle dung treatment while lowest germination percentage (70\%) was recorded in both types of seed grown without vermicompost and cattle dung treatment. It was also found that highest germination percentages of Wheat and Urad seeds were recorded grown with vermicompost treated soil than cattle dung treated soil. A germination study of Wheat and Urad seed grown under various doses of vermicompost and cattle dung treatment is shown in table no.2.

Table 2. Germination percentage of both Wheat and Urad plant in different proportions of vermicompost/cattle dung with soil

\begin{tabular}{|l|c|c|c|c|c|}
\hline \multicolumn{3}{|c|}{ Vermicompost treated soil } & \multicolumn{3}{c|}{ Cattle dung treated soil } \\
\hline Proportion & $\begin{array}{c}\text { Average } \\
\text { germination } \\
\text { \% of Wheat } \\
\text { plant }\end{array}$ & $\begin{array}{c}\text { Average } \\
\text { germination } \\
\text { \% of Urad plant }\end{array}$ & Proportion & $\begin{array}{c}\text { Average } \\
\text { germination } \\
\text { \% of Wheat } \\
\text { plant }\end{array}$ & $\begin{array}{c}\text { Average } \\
\text { germination } \\
\% \text { of Urad plant }\end{array}$ \\
\hline $100 \%$ VC & 85 & 70 & $100 \%$ CD & 80 & 80 \\
\hline $75 \%$ VC & 90 & 90 & $75 \%$ CD & 85 & 85 \\
\hline $50 \%$ VC & 100 & 100 & $50 \%$ CD & 100 & 100 \\
\hline $25 \%$ VC & 85 & 90 & $25 \%$ CD & 80 & 80 \\
\hline $100 \%$ Soil & 70 & 70 & $100 \%$ Soil & 70 & 70 \\
\hline
\end{tabular}

\section{Length measurement}

The length of Wheat and Urad plant were measured in centimeter. The highest length of Urad plant was recorded in soil treated with $50 \%$ Vermicompost $(22.60 \mathrm{~cm}$.) and $50 \%$ cattle dung $(17.80 \mathrm{~cm}$.) while lowest length was recorded in $100 \%$ vermicompost $(2.3 \mathrm{~cm})$ and $100 \%$ cattle dung $(12.95 \mathrm{~cm}$.). It was also found that the highest growth recorded in soil treated with vermicompost than soil treated with cattle dung (Table no.3,fig. no.5, 6 \& 7).

Table 3: Effect of vermicompost/cattle dung -soil mixture on the length of Urad plant

\begin{tabular}{|l|l|l|l|l|l|l|l|l|l|l|}
\hline \multirow{2}{*}{ Date } & $\mathbf{1 0 0} \%$ soil & \multicolumn{2}{l|}{$\mathbf{7 5} \%$ soil } & \multicolumn{2}{l|}{$\mathbf{5 0} \%$ soil } & \multicolumn{2}{l|}{$\mathbf{2 5} \%$ soil } & \multicolumn{2}{l|}{$\mathbf{1 0 0} \%$ Control } \\
\cline { 2 - 11 } & Soil & Soil & VC & CD & VC & CD & VC & CD & VC & CD \\
\hline $\mathbf{2 4 / 0 2 / 2 0 1 4}$ & 0.00 & 0.00 & 0.00 & 0.00 & 0.00 & 0.00 & 0.00 & 0.00 & 0.00 & 0.00 \\
\hline $\mathbf{2 5 / 0 2 / 2 0 1 4}$ & 0.00 & 0.00 & 0.00 & 0.00 & 0.00 & 0.00 & 0.00 & 0.00 & 0.00 & 0.00 \\
\hline $\mathbf{2 6 / 0 2 / 2 0 1 4}$ & 1.00 & 0.65 & 1.35 & 0.75 & 2.30 & 1.35 & 1.30 & 1.40 & 0.00 & 1.10 \\
\hline $\mathbf{2 7 / 0 2 / 2 0 1 4}$ & 1.35 & 1.35 & 0.90 & 1.95 & 1.55 & 0.95 & 0.65 & 1.20 & 0.00 & 0.90 \\
\hline $\mathbf{2 8 / 0 2 / 2 0 1 4}$ & 1.15 & 1.00 & 1.35 & 0.75 & 1.65 & 1.50 & 1.25 & 1.20 & 0.00 & 1.20 \\
\hline
\end{tabular}


“Comparative Study of Soil Mixed vermicompost and Cattle Dung on the Growth Parameters of Triticum astivum (Wheat) and Faciolus mungo (Urad) Plant"

\begin{tabular}{|l|l|l|l|l|l|l|l|l|l|l|}
\hline $\mathbf{0 1 / 0 3 / 2 0 1 4}$ & 1.05 & 1.25 & 1.25 & 1.35 & 2.15 & 1.50 & 0.85 & 0.60 & 0.00 & 1.30 \\
\hline $\mathbf{0 2 / 0 3 / 2 0 1 4}$ & 0.90 & 1.00 & 1.50 & 1.15 & 2.55 & 1.50 & 1.25 & 0.90 & 0.00 & 0.75 \\
\hline $\mathbf{0 3 / 0 3 / 2 0 1 4}$ & 1.10 & 1.05 & 1.25 & 0.97 & 2.90 & 2.50 & 1.70 & 1.20 & 0.00 & 1.00 \\
\hline $\mathbf{0 4 / 0 3 / 2 0 1 4}$ & 2.35 & 1.30 & 1.80 & 1.18 & 2.15 & 2.00 & 1.10 & 1.15 & 0.00 & 0.85 \\
\hline $\mathbf{0 5 / 0 3 / 2 0 1 4}$ & 1.45 & 2.15 & 1.80 & 1.05 & 1.95 & 1.15 & 0.70 & 1.40 & 0.00 & 1.20 \\
\hline $\mathbf{0 6 / 0 3 / 2 0 1 4}$ & 2.05 & 1.30 & 1.65 & 0.95 & 1.40 & 1.85 & 1.40 & 0.90 & 1.30 & 1.25 \\
\hline $\mathbf{0 7 / 0 3 / 2 0 1 4}$ & 0.90 & 1.20 & 1.30 & 1.00 & 1.40 & 1.30 & 1.00 & 1.00 & 1.00 & 1.20 \\
\hline $\mathbf{0 8 / 0 3 / 2 0 1 4}$ & 0.80 & 1.20 & 1.30 & 1.00 & 1.30 & 1.20 & 1.00 & 1.00 & 0.00 & 1.10 \\
\hline $\mathbf{0 9 / 0 3 / 2 0 1 4}$ & 0.80 & 1.20 & 1.30 & 1.10 & 1.30 & 1.00 & 1.00 & 1.00 & 0.00 & 1.10 \\
\hline Total & $\mathbf{1 4 . 9 0}$ & $\mathbf{1 4 . 6 5}$ & $\mathbf{1 6 . 7 5}$ & $\mathbf{1 3 . 2 0}$ & $\mathbf{2 2 . 6 0}$ & $\mathbf{1 7 . 8 0}$ & $\mathbf{1 3 . 2 0}$ & $\mathbf{1 2 . 9 5}$ & $\mathbf{0 2 . 3 0}$ & $\mathbf{1 2 . 9 5}$ \\
\hline
\end{tabular}

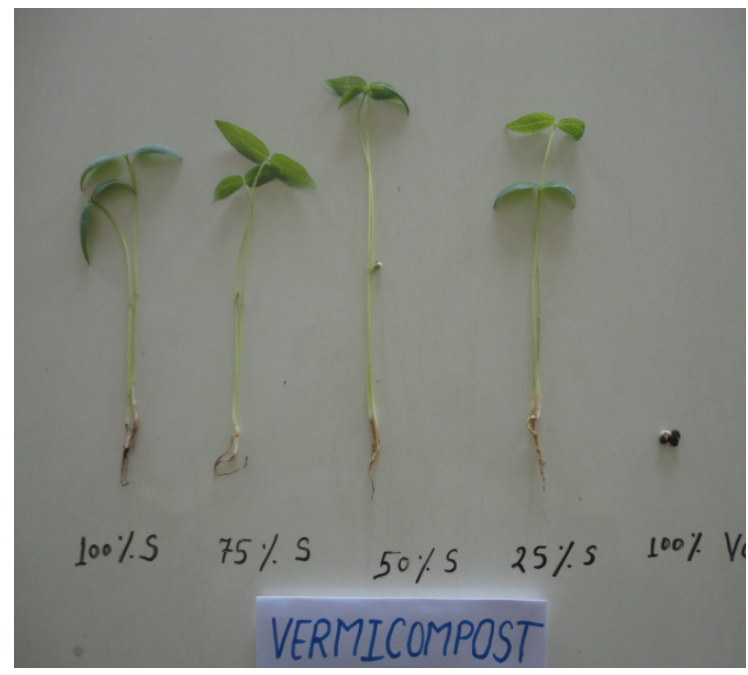

Fig5. Effect of vermicompost-soil mixtures on the length of Urad plant.

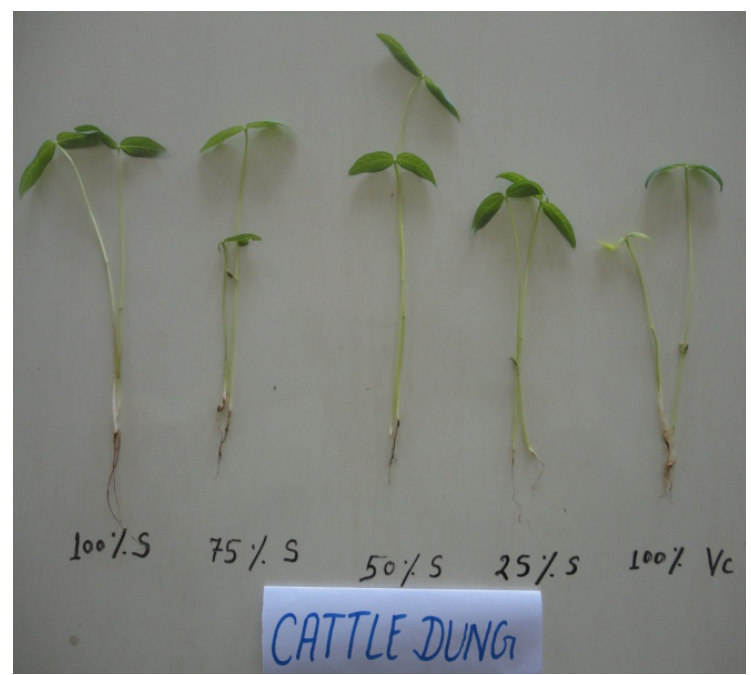

Fig6. Effect of cattle dung-soil mixtures on the length of Urad plant

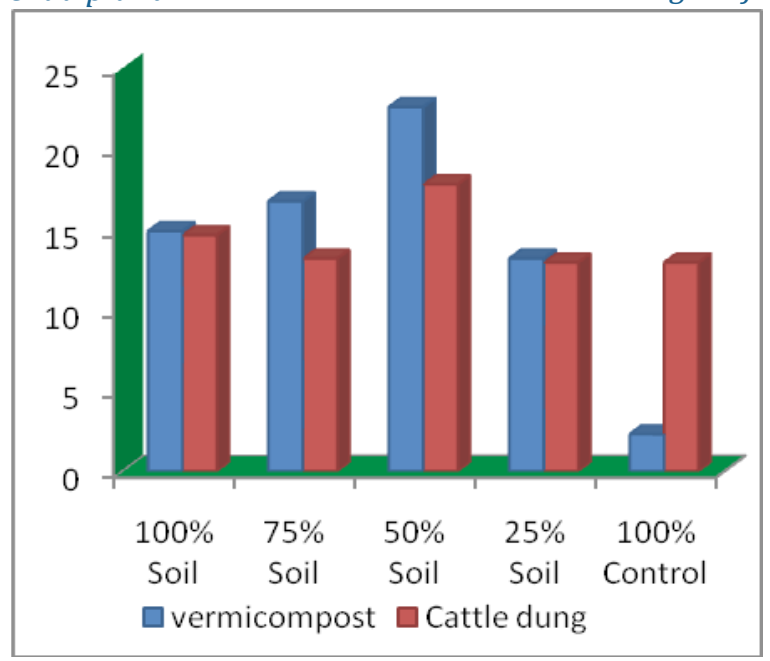

Fig7. Effect of different proportion of soil-compost mixtures on the length of Urad plant. 
“Comparative Study of Soil Mixed vermicompost and Cattle Dung on the Growth Parameters of Triticum astivum (Wheat) and Faciolus mungo (Urad) Plant"

The highest length of Wheat plant was recorded in soil treated with $50 \%$ Vermicompost $(26.70 \mathrm{~cm}$.) and $50 \%$ cattle dung (24.15 cm.) while lowest length was recorded in $100 \%$ soil $(13.35 \mathrm{~cm})$. It has also found that,highest length recorded in soil treated with vermicompost than cattle dung treated soil (Table no.4,fig. no.3,4\&8).

Table 4. Effect of vermicompost/cattle dung-soil mixture on the length of Wheat plant

\begin{tabular}{|c|c|c|c|c|c|c|c|c|c|c|}
\hline \multirow[t]{2}{*}{ Date } & \multicolumn{2}{|c|}{$100 \%$ soil } & \multicolumn{2}{|c|}{$75 \%$ soil } & \multicolumn{2}{|c|}{$50 \%$ soil } & \multicolumn{2}{|c|}{$25 \%$ soil } & \multicolumn{2}{|c|}{$100 \%$ Control } \\
\hline & Soil & Soil & VC & CD & VC & CD & VC & CD & VC & CD \\
\hline $24 / 02 / 2014$ & 0.00 & 0.00 & 0.00 & 0.00 & 0.00 & 0.00 & 0.00 & 0.00 & 0.00 & 0.00 \\
\hline $25 / 02 / 2014$ & 0.00 & 0.00 & 0.00 & 0.00 & 0.00 & 0.00 & 0.00 & 0.00 & 0.00 & 0.00 \\
\hline $26 / 02 / 2014$ & 1.05 & 1.95 & 1.70 & 2.25 & 2.35 & 2.90 & 1.15 & 3.15 & 1.35 & 1.55 \\
\hline $27 / 02 / 2014$ & 1.05 & 0.00 & 0.55 & 1.60 & 1.20 & 1.40 & 1.09 & 1.80 & 1.79 & 1.75 \\
\hline $28 / 02 / 2014$ & 0.95 & 1.30 & 1.65 & 1.25 & 2.20 & 1.70 & 1.51 & 2.05 & 1.66 & 2.05 \\
\hline $01 / 03 / 2014$ & 1.05 & 1.05 & 1.50 & 1.95 & 1.55 & 2.00 & 1.40 & 1.70 & 1.15 & 1.50 \\
\hline $02 / 03 / 2014$ & 1.00 & 1.60 & 1.95 & 1.50 & 1.50 & 2.60 & 1.95 & 2.70 & 1.95 & 1.70 \\
\hline $03 / 03 / 2014$ & 1.00 & 0.95 & 1.35 & 2.65 & 1.95 & 3.00 & 1.30 & 2.80 & 1.65 & 1.65 \\
\hline $04 / 03 / 2014$ & 1.05 & 1.50 & 1.37 & 2.55 & 2.55 & 1.80 & 1.70 & 3.00 & 1.50 & 1.75 \\
\hline $05 / 03 / 2014$ & 1.20 & 1.20 & 2.55 & 2.65 & 2.20 & 2.35 & 1.35 & 2.25 & 2.30 & 2.35 \\
\hline $06 / 03 / 2014$ & 1.30 & 1.35 & 1.95 & 2.60 & 3.10 & 2.10 & 1.90 & 3.25 & 1.30 & 1.30 \\
\hline $07 / 03 / 2014$ & 1.30 & 1.20 & 1.60 & 1.70 & 3.10 & 1.50 & 1.50 & 2.00 & 1.30 & 1.10 \\
\hline $08 / 03 / 2014$ & 1.20 & 1.10 & 1.60 & 1.50 & 2.80 & 1.40 & 1.50 & 1.10 & 1.20 & 1.10 \\
\hline $09 / 03 / 2014$ & 1.20 & 1.10 & 1.50 & 1.50 & 2.20 & 1.40 & 1.40 & 1.10 & 1.20 & 1.10 \\
\hline Total & 13.35 & 14.30 & 19.27 & 23.70 & 26.70 & 24.15 & 17.75 & 26.90 & 18.35 & 18.90 \\
\hline
\end{tabular}

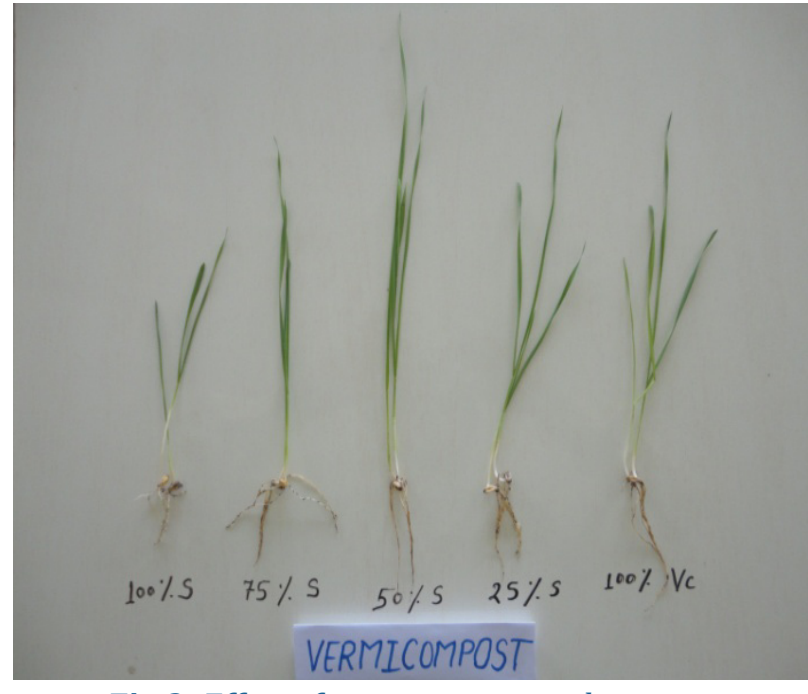

Fig 3. Effect of vermicompost-soil mixtures on the length of Wheat plant.

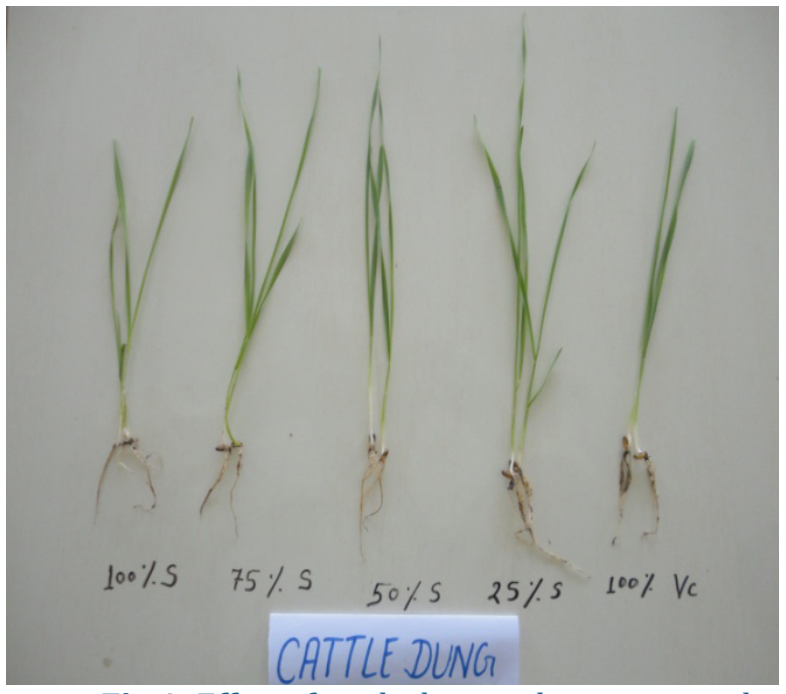

Fig 4. Effect of cattle dung-soil mixtures on the length of Wheat plant. 
“Comparative Study of Soil Mixed vermicompost and Cattle Dung on the Growth Parameters of Triticum astivum (Wheat) and Faciolus mungo (Urad) Plant"

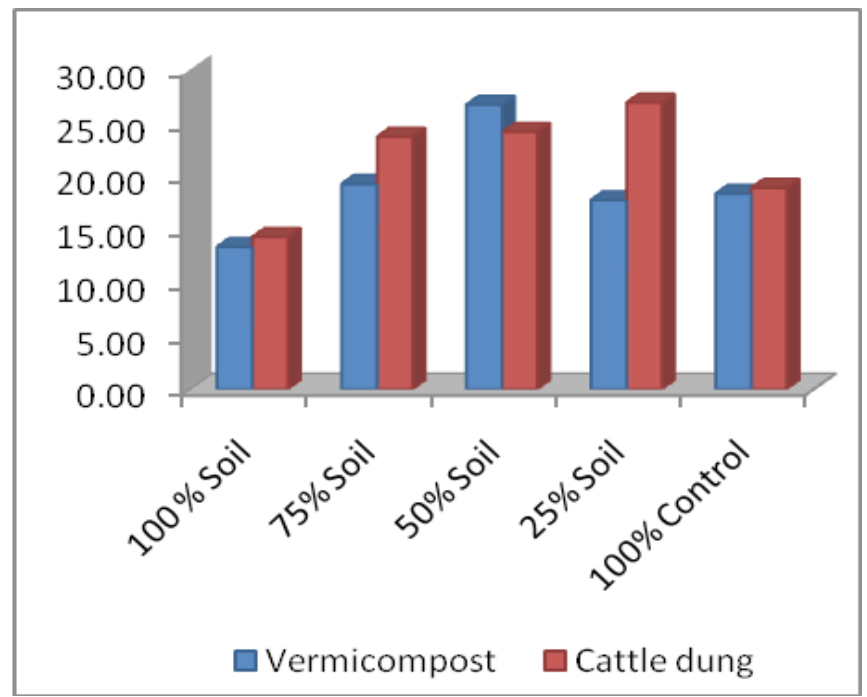

Fig 8. Effect of different proportion of soil-compost mixtures on the length of Wheat plant

\section{Dry weight measurement}

The highest dry weight of Urad plant shoot was recorded $90 \mathrm{mg}$ grown in $50 \%$ soil treated with vermicompost and $75 \mathrm{mg}$ in $50 \%$ soil treated with cattle dung while lowest dry weight was recorded $30 \mathrm{mg}$ grown in $100 \%$ vermicompost and $60 \mathrm{mg}$ in $100 \%$ soil (Fig.9). The highest dry weight of Urad plant root was recorded $40 \mathrm{mg}$ (50\% soil treated with vermicompost) and $35 \mathrm{mg}$ (50\% soil treated with cattle dung) while lowest dry weight recorded were $15 \mathrm{mg}$ (100\% vermicompost) and $25 \mathrm{mg}$ (100\% soil) respectively (Table no.5 and fig.10).

Table 5. Effect of different proportion of vermicompost/cattle dung-soil mixtures on dry weight of Urad plant.

\begin{tabular}{|l|l|c|c|c|c|}
\hline \multirow{4}{*}{ Combination } & \multicolumn{2}{|c|}{ Proportion } & \multicolumn{2}{c|}{ Average Shoot weight(mg) } & \multicolumn{2}{c|}{$\begin{array}{c}\text { Average Root weight } \\
\text { (mg) }\end{array}$} \\
\cline { 3 - 6 } & & Biomass & Dry mass & Biomass & Dry mass \\
\hline \multirow{3}{*}{ Soil with } & & 290 & 60 & 120 & 25 \\
\cline { 2 - 6 } & $100 \%$ Soil & 310 & 60 & 130 & 35 \\
\cline { 2 - 6 } & $75 \%$ Soil & 335 & 75 & 145 & 35 \\
\cline { 2 - 6 } & $50 \%$ Soil & 320 & 70 & 140 & 30 \\
\cline { 2 - 6 } & $25 \%$ Soil & 330 & 75 & 140 & 30 \\
\cline { 2 - 6 } Vermicompost & $100 \%$ Cattle dung & 320 & 70 & 150 & 35 \\
\cline { 2 - 6 } & $100 \%$ Soil & 350 & 75 & 160 & 35 \\
\cline { 2 - 6 } & $75 \%$ Soil & 410 & 90 & 180 & 40 \\
\cline { 2 - 6 } & $50 \%$ Soil & 410 & 90 & 180 & 40 \\
\cline { 2 - 6 } & $25 \%$ Soil & 130 & 30 & 060 & 15 \\
\cline { 2 - 6 } & $100 \%$ Vermicompost & & & & \\
\hline
\end{tabular}


“Comparative Study of Soil Mixed vermicompost and Cattle Dung on the Growth Parameters of Triticum astivum (Wheat) and Faciolus mungo (Urad) Plant"

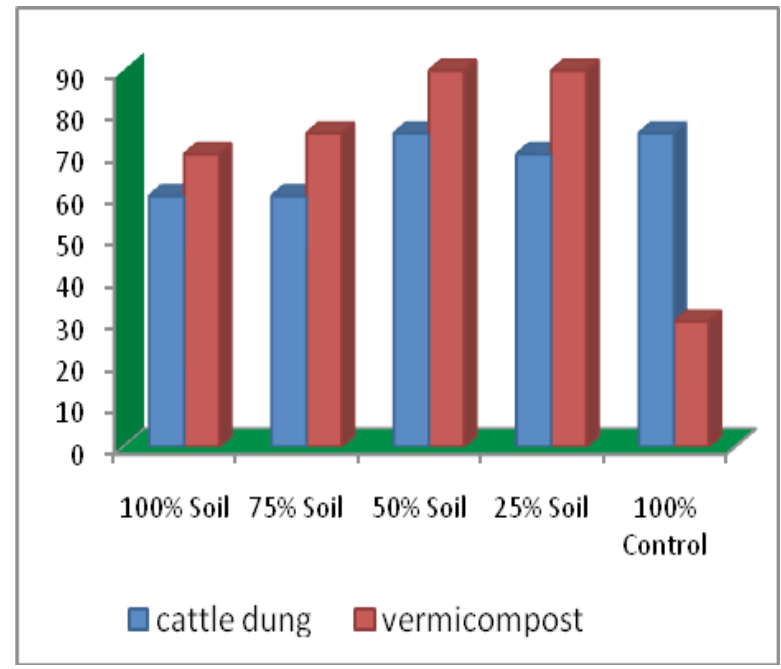

Fig 9. Dry weight (mg) measurement of shoot of Urad plant.

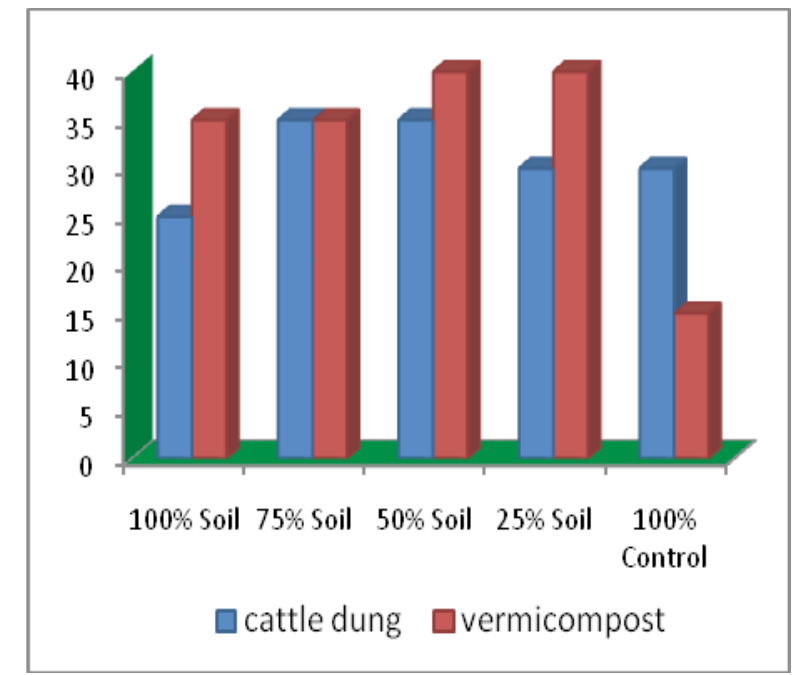

Fig 10. Dry weight (mg) measurement of root of Urad plant.

The highest dry weight of Wheat plant shoot was recorded $110 \mathrm{mg}$ grown in $50 \%$ soil treated with vermicompost and $100 \mathrm{mg}$ in $25 \%$ soil treated with cattle dung. The lowest dry weight shoot of Wheat plant was recorded 60 mg grown in $100 \%$ vermicompost and $50 \mathrm{mg}$ in $100 \%$ soil (Fig.11). The highest dry weight of Wheat plant root was recorded $50 \mathrm{mg}$ grown in 50\% soil treated with vermicompost and $40 \mathrm{mg}$ in $25 \%$ soil treated with cattle dung. The lowest dry weight root of Wheat plant was recorded $25 \mathrm{mg}$ grown in $100 \%$ soil and $25 \mathrm{mg}$ in $50 \%$ soil treated with cattle dung (Table no.6 and fig.12).

Table 6. Effect of different proportion of vermicompost/cattle dung-soil mixtures on dry weight of Wheat plant

\begin{tabular}{|l|l|c|c|c|c|}
\hline \multirow{4}{*}{ Combination } & \multirow{2}{*}{ Proportion } & \multicolumn{2}{c|}{ Average Shoot weight(mg) } & \multicolumn{2}{c|}{ Average Root weight (mg) } \\
\cline { 3 - 6 } & Biomass & Dry mass & Biomass & Dry mass \\
\hline \multirow{3}{*}{$\begin{array}{l}\text { Soil with } \\
\text { Cattle dung }\end{array}$} & $100 \%$ Soil & 220 & 50 & 110 & 30 \\
\cline { 2 - 6 } & $75 \%$ Soil & 320 & 60 & 140 & 30 \\
\cline { 2 - 6 } & $50 \%$ Soil & 280 & 50 & 120 & 25 \\
\cline { 2 - 6 } & $25 \%$ Soil & 440 & 100 & 190 & 40 \\
\cline { 2 - 6 } & $100 \%$ Cattle dung & 370 & 80 & 160 & 35 \\
\hline \multirow{5}{*}{\begin{tabular}{l} 
Voil with \\
\cline { 2 - 6 }
\end{tabular}} & $100 \%$ Soil & 310 & 70 & 120 & 25 \\
\cline { 2 - 6 } & $75 \%$ Soil & 320 & 75 & 130 & 30 \\
\cline { 2 - 6 } & $50 \%$ Soil & 500 & 110 & 210 & 50 \\
\cline { 2 - 6 } & $25 \%$ Soil & 385 & 80 & 165 & 40 \\
\cline { 2 - 6 } & $100 \%$ Vermicompost & 330 & 60 & 140 & 30 \\
\hline
\end{tabular}


“Comparative Study of Soil Mixed vermicompost and Cattle Dung on the Growth Parameters of Triticum astivum (Wheat) and Faciolus mungo (Urad) Plant"

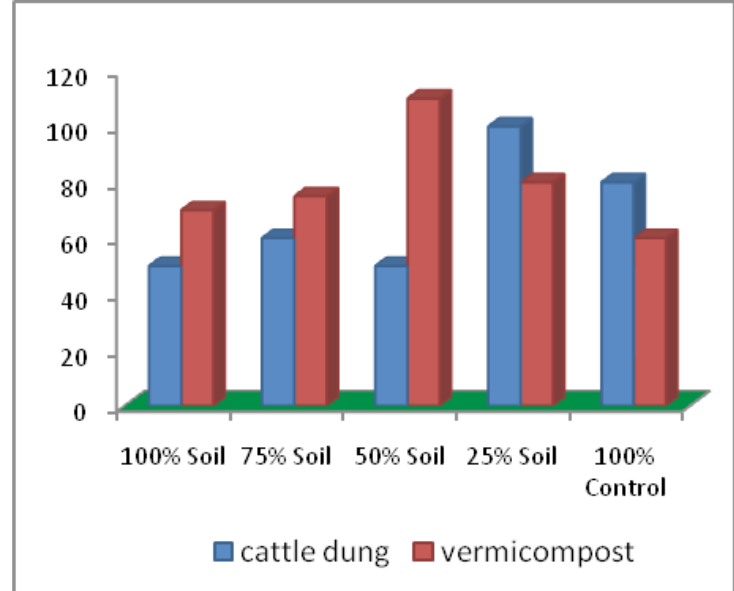

Fig 11. Dry weight $(\mathrm{mg})$ measurement of shoot of Wheat plant.

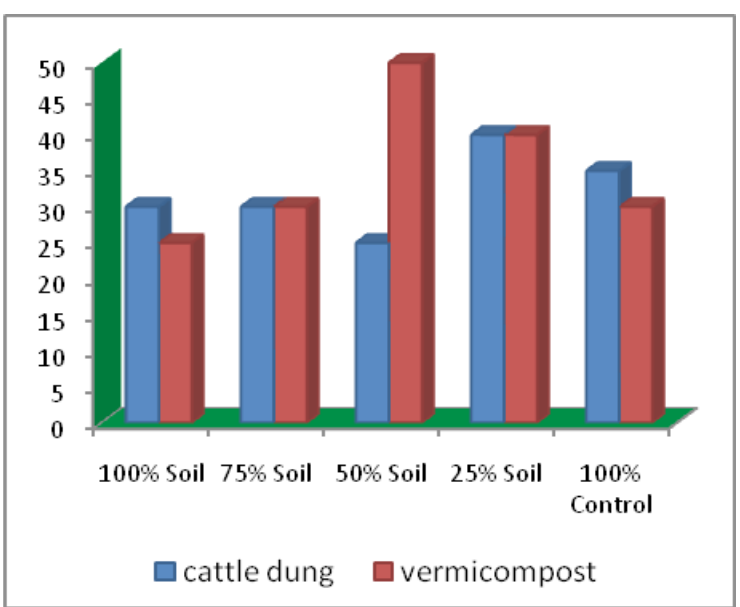

Fig 12. Dry weight (mg) measurement of root of Wheat plant

\section{Chlorophyll detection}

The consequence of different proportion of vermicompost and cattle dung mixed soil on the synthesis of chlorophyll pigment of Wheat and Urad plant leaves are presented in Table 7. The highest chlorophyll contents of Urad plant were measured $46.25 \mathrm{mg} / \mathrm{Lit}$ and $52.34 \mathrm{mg} / \mathrm{Lit}$ in $50 \%$ soil treated with cattle dung and $50 \%$ soil treated with vermicompost respectively while lowest chlorophyll contentwas recorded in $100 \%$ soil $(33.32 \mathrm{mg} /$ Lit) and $100 \%$ vermicompost (21.22mg/Lit).

Table 7. Chlorophyll contents of both Wheat and Urad plant leaf under influence of different proportions of vermicompost and cattle dung mixed soil.

\begin{tabular}{|l|l|c|c|}
\hline \multirow{4}{*}{ Combination } & \multicolumn{1}{|c|}{ Proportion } & $\begin{array}{c}\text { Chlorophyll Content Of } \\
\text { Urad plant leaf } \\
\text { (mg./Liter) }\end{array}$ & $\begin{array}{c}\text { Chlorophyll Content Of } \\
\text { Wheat plant leaf } \\
\text { (mg./Liter) }\end{array}$ \\
\hline \multirow{4}{*}{$\begin{array}{l}\text { Soil with } \\
\text { Cattle dung }\end{array}$} & $100 \%$ Soil & 33.32 & 28.34 \\
\cline { 2 - 4 } & $75 \%$ Soil & 41.21 & 37.45 \\
\cline { 2 - 4 } & $50 \%$ Soil & 46.25 & 43.33 \\
\cline { 2 - 4 } & $25 \%$ Soil & 42.20 & 40.45 \\
\cline { 2 - 4 } & $100 \%$ Cattle dung & 43.13 & 39.22 \\
\hline \multirow{3}{*}{ Soil with } & $100 \%$ Soil & 34.12 & 32.31 \\
\cline { 2 - 4 } & $75 \%$ Soil & 40.23 & 38.62 \\
\cline { 2 - 4 } & $50 \%$ Soil & 52.34 & 44.35 \\
\cline { 2 - 4 } & $25 \%$ Soil & 43.45 & 40.74 \\
\cline { 2 - 4 } & $100 \%$ Vermicompost & 21.22 & 38.13 \\
\hline
\end{tabular}


“Comparative Study of Soil Mixed vermicompost and Cattle Dung on the Growth Parameters of Triticum astivum (Wheat) and Faciolus mungo (Urad) Plant"

The highest chlorophyll contents of Wheat plant leaf were recorded $43.33 \mathrm{mg} / \mathrm{lit}$ (50\% soil treated with cattle dung) and $44.35 \mathrm{mg} / \mathrm{Li} \mathrm{(50 \%} \mathrm{soil} \mathrm{treated} \mathrm{with} \mathrm{vermicompost)} \mathrm{and} \mathrm{the} \mathrm{lowest} \mathrm{was} 28.33 \mathrm{mg} / \mathrm{Lit} 100 \%$ soil.

\section{Carotenoid detection}

The effect of different quantities of vermicompost and cattle dung containing soil on the carotenoid pigment synthesis of Wheat and Urad plant also determined are depicted in table no. 8. The highest carotenoid pigments synthesis were recorded in Urad plant grown in $50 \%$ of vermicompost treated soil (654.25 mg/Lit) and $50 \%$ cattle dung treated soil (576.24 mg/Lit) while lowest value recorded in $100 \%$ vermicompost (128.24 mg/Lit) and in $100 \%$ soil ( $472.56 \mathrm{mg} / \mathrm{Lit})$.

Table 8. Carotenoid contents of both Wheat and Urad plant leaf under influence of different proportions of vermicompost and cattle dung mixed soil

\begin{tabular}{|l|l|c|c|}
\hline \multirow{5}{*}{ Combination } & \multicolumn{1}{|c|}{ Proportion } & $\begin{array}{c}\text { Carotenoid Content } \\
\text { of Urad plant leaf } \\
\text { (mg./Liter) }\end{array}$ & $\begin{array}{c}\text { Carotenoid Content } \\
\text { of Wheat plant leaf } \\
\text { (mg./Liter) }\end{array}$ \\
\hline \multirow{4}{*}{$\begin{array}{l}\text { Soil with } \\
\text { Cattle dung }\end{array}$} & $100 \%$ Soil & 472.56 & 390.25 \\
\cline { 2 - 4 } & $75 \%$ Soil & 508.47 & 435.59 \\
\cline { 2 - 4 } & $50 \%$ Soil & 576.24 & 498.34 \\
\cline { 2 - 4 } & $25 \%$ Soil & 535.12 & 450.31 \\
\cline { 2 - 4 } & $100 \%$ Cattle dung & 490.78 & 413.48 \\
\hline \multirow{4}{*}{$\begin{array}{l}\text { Voil with } \\
\text { Vermicompost }\end{array}$} & $100 \%$ Soil & 423.35 & 401.25 \\
\cline { 2 - 4 } & $75 \%$ Soil & 542.25 & 469.42 \\
\cline { 2 - 4 } & $50 \%$ Soil & 654.25 & 531.29 \\
\cline { 2 - 4 } & $25 \%$ Soil & 510.56 & 486.43 \\
\cline { 2 - 4 } & $100 \%$ Vermicompost & 128.24 & 412.45 \\
\hline
\end{tabular}

The highest carotenoid pigment of Wheat plant recorded were $498.34 \mathrm{mg} / \mathrm{Lit}$ and $531.29 \mathrm{mg} / \mathrm{Lit}$ in $50 \%$ soil treated with cattle dung and $50 \%$ soil treated with vermicompost respectively. The lowest carotenoid pigment was recorded in $100 \%$ soil (390.25 mg/Lit) and $100 \%$ vermicompost (401.25 mg/Lit).

\section{DiscusSion}

Presence of nutrients in a soil is essential for sustainable agricultural practice. Regular cultivation of crops exhausts soil nutrients that can be fulfilled by addition of supplement i.e. fertilizers. Using of organic matter such as animal manures has long been recognized in agriculture as beneficial for plant growth and yield and the maintenance of soil fertility.In present study, different proportions of vermicompost and cattle dung compost with soil were used on Wheat and Urad plant to evaluate their effects viz. germination percentage, height of plant, dry weight, and photosynthetic pigments. The seed germination test is performed to evaluate the recommended dose of appropriate compost to stimulate plant growth and yield.In the present study of seed germination, it was found that highest germination of Wheat and Urad seeds occur in $50 \%$ soil mixed with eitherby vermicompost or by cattle dung than control soil. Similler finding also recorded in the seed germination percentage of groundnut when compare with control (Mathivanan, et.al. 2012). The highest germination percentage was also observed in radish grown in vermicompost treated soil compared to the control soil(Buckerfield, et.al. 1999). 
“Comparative Study of Soil Mixed vermicompost and Cattle Dung on the Growth Parameters of Triticum astivum (Wheat) and Faciolus mungo (Urad) Plant"

The application of vermicompost increased the height of plants due to present of essential nutrients. In the experiment, the highest length of Wheat and Urad plants was recorded in $50 \%$ soiltreated with vermicompost as compaired to cattle dung treated soil and control soil. This finding supported by several researchers who find out that growth and development of plants is due to the presence of humic acids (Arancon et al. 2005) and micro and macronutrients present abundantlyin vermicompost (Atiye et al., 2002; Fernández-Luqueño et al. 2010). Hadi, et al. (2011) was observed that, the height of Matricaria chamomomile plant significantly increased when vermicompost was applied at the rate of $20 \mathrm{t} / \mathrm{ha}$. The height of maize plant was also recorded by Gutie'rrez-Miceli et al. (2008) when grown in soil mixed with vermicompost.Similarly, vermicompost amendments increased plant a height of potato was reported by Alam et al. (2007) and Vijaya and Seethalakshmi (2011).

A significant increased concentration of photosynthetic pigments viz. Chlorophyll and Carotenoid were also observed in Wheat and Urad plant grown in vermicompost treated soil. In a study, Azarmi et al. (2009) reported that chlorophyll content of leaves of cucumber increased due to addition of vermicompost applications. Taleshi et al. (2011) reported that the available form of nitrogen (nitrate) is high in vermicompost than conventionally composted manure which is required for pigment synthesis.It was observed that addition of $8.2 \% \mathrm{w} / \mathrm{w}$ vermicompost /soil induced the largest increase in chlorophyll content in the leaves of common bean plants (Fernández, et.al.,2010). Berova, et.al. (2009) also found increasing concentration of photosynthetic pigments in leaf of Capsicum annuum plant is due to application of vermicompost.

The growth parameters of Wheat and Urad plant such as shoot and root dry weights were better in vermicompost treated soil than the cattle dung treated soil. Our results corroborate with the findings of other investigators that reported significant increase in growth parameters of plants after application of vermicompost in the growth media (Tomati, et.al., 1990 ; Joshi and Vig, 2010 and Bachman and Metzger, 2008). Scientists of different agricultural fields agreed that plant growth and development are strictly dependent on biological fertility factors. Earthworms may stimulate microbial activities and metabolism and also influence microbial populations. As a consequence, more available nutrients and microbial metabolites are released into the soil (Edwards, 1988).

\section{CONCLUSION}

Supplementation of nutrient to a soil is a good practice for agricultural but should not be short acting and cost effective.Therefore, it is necessary to arrange complementary resources which can long acting and minimize the use of chemical fertilizer. Although cattle dung is better solution but it can be excellent if it is processed by earthworm. Present study revealed that by using of vermicompost,seed germination rate increased that enhance the more number of seeds in soil as a plant. It also increased the length of plant that direct the more surface area for arising of leaf, flower and pod. By using of vermicompost, chlorophyll content also increased as compaired to cattle dung treated plant showed more production of Wheat and Urad.

\section{ACKNOWLEDGMENTS}

The authors wish to express their warm gratitude to the Director and governing body of Advance College, Ujjain to conduct this research work. We are also thankful to Principal, Govt. Madhav Science College for providing vermicompost to this experiment. 
“Comparative Study of Soil Mixed vermicompost and Cattle Dung on the Growth Parameters of Triticum astivum (Wheat) and Faciolus mungo (Urad) Plant"

\section{REFERENCES}

- Aira M, Monroy F, Dominguez J, Mato S (2000) How earthworm density affects microbial biomass and activityin pig manure. European J Soil Biol 38:7-10

- Alam MN, Jahan MS, Ali MK, Ashraf MA, Islam MK (2007) Effect of vermicompost and chemical fertilizers on growth, yield and yield components of potato in barind soils of Bangladesh. J ApplSci Res 3(12):1879-1888.

- Ansari AA, Kumar Sukhraj K (2010) Effect of vermiwash and vermicompost on soil parameters and productivity of okra (Abelmoschus esculentus) in Guyana. African Journal of Agricultural Research 5(14):1794-1798.

- Arancon NQ, Edwards CA, Bierman P, Metzger JD, Lucht C (2005) Effects of vermicomposts produced from cattle manure, food waste and paper waste on the growth and yield of peppers in the field.Pedobiologia 49(2005):297-306.

- Arnon,D.I.(1949).Copper Enzymes in Isolated Chloroplast Polyphenoloxidase in Beta Vulgarise Plant Physiology.24(1-16)

- Atiyeh RM, Edwards CA, Metzer JD, Lee S, Arancon NQ (2002) The influence of humic acids derived from earthworm-processed organic wastes on plant growth. BioresourTechnol 84:7-14

- Azarmi R, Giglou MT, Taleshmikail RD (2009) Influence of vermicompost on soil chemical and physical properties in tomato (Lycopersicum esculentum) field. Afr J Biotechnol 7(14):2397-2401.

- Bachman, G.R. and Metzger, J.D. (2008) Growth of Bedding Plants in Commercial Potting Substrate Amended with Vermicompost. Bioresource Technology, 99, 3155-3161.

- Berova M, Karanatsdis G .Influence of bio-fertilizer, produced by Lumbricus rubellus growth, leaf gas exchange and photosynthetic content of pepper plants (Capsicum annuumL.). Acta Hort., 830: (2009). 447-452.

- $\quad$ Buckerfield , J.C., Flavel, T., Lee, K.E., and Webster, K.A. (1999) vermicomposts in solid and liquid form as plant-growth promoter. Pedobiolgia. 43: 753-759.

- Buckerfield, J. C. and K. A. Webster. (1998) Worm-worked waste boosts grape yields: prospects for vermicompost use in vineyards. The Australian and New Zealand Wine Industry Journal, 13: 73-76.

- Chan, P.L.S. and D.A. Griffiths. (1988) The vermicomposting of pre-treated pig manure. Biological Wastes, 24: 57-69.

- $\quad$ Edwards, C. A. and Burrows, I. (1988) The potential of earthworm composts as plant growth media. In Earthworms in Environmental and Waste Management Ed. C. A., Neuhauser, SPB Academic Publ. b.v. The Netherlands. 211-220.

- Fernández-Luqueño F, Reyes-Varela V, Martínez-Suárez C, Salomón- Hernández G, Yáñez-Meneses J, Ceballos-Ramírez JM, Dendooven L Effect of different nitrogen sources on plant characteristics and yield of common bean (Phaseolus vulgaris L.). Biores. Technol., 101: (2010). 396-403. 
“Comparative Study of Soil Mixed vermicompost and Cattle Dung on the Growth Parameters of Triticum astivum (Wheat) and Faciolus mungo (Urad) Plant"

- Gutie'rrez-Miceli FA, Moguel-Zamudio B, Abud-Archila M, Gutie'rrez-Oliva VF, Dendooven L (2008) Sheep manure vermicompost supplemented with a native diazotrophic bacteria and mycorrhizas for maize cultivation. BioresourTechnol 99:7020-7026.

- Hadi MRHS, Darz MT, Ghandehari Z, Riazi G (2011) Effects of vermicompost and amino acids on the flower yield and essential oil production from Matricaria chamomile L. Journal of Medicinal Plants Research 5(23):5611-5617.

- Hameeda B, Harini G, Rupela OP, Reddy G (2007) Effect of composts or vermicomposts on sorghum growth and mycorrhizal colonization. Afr J Biotechnol 6(1):009-012.

- Hoitink, H.A.J. 1993. Proceedings Review: International Symposium on composting research. Compost Science and Utilization. Spring 1993: 37.

- Javed S, Panwar A(2013) Effect of biofertilizer, vermicompost and chemical fertilizer on different biochemical parameters of Glycine max and Vigna mungo. Recent Research in Science and Technology 5(1):40-44.

- Joshi, R.; Adarsh, P. and Singh, J., Vermicompost as soil supplement to enhance growth, yield and quality of Triticum aestivum L.: a field study. International Journal of Recycling of Organic Waste in Agriculture 2013, $2: 16$.

- Joshi, R. and Vig, A.P. (2010) Effect of Vermicompost on Growth, Yield and Quality of Tomato (Solanum lycopersicum L.). African Journal of Basic Applied Sciences, 2, 117-123.

- Lazcano C, Arnold J, Tato A,J, Zaller JG, Domínguez J (2009) Compost and vermicompost as nursery pot components:effects on tomato plant growth and morphology. Span J Agric Res 7(4):944-951.

- Masciandaro, G., B. Ceccanti and C. Garcia. 1997. Soil agro-ecological management: fertirrigation and vermicompost treatments. Bioresource Technology, 59: 199-206.

- Mathivanan, S.; Chidambaram, AL. A.; Sundaramoorthy, P. and Kalaikandhan, R. (2012). Effect of vermicompost on germination and biochemical constituents of ground nut (Arachis hypogaea. l.) seedling. International Journal of Research in Biological Sciences . 2 (2): 54-59.

- Mirakalaei SMM, Ardebill ZO, Mostafavi M (2013) The effects of different organic fertilizers on the growth of lilies (Lillium longiflorum). International Research Journal of Applied and Basic Sciences 4(1):181-186.

- Mycin TR, Lenin M, Selvakumar G, Thangadurai R(2010) Growth and nutrient Content Variation of Groundnut ArachishypogaeaL.under Vermicompost Application. Journal of Experimental Sciences 1(8):12-16.

- Paul S, Bhattacharya SS (2012) Vermicomposted Water Hyacinth Enhances Growth and Yield of Marigold by Improving Nutrient Availability in Soils of North Bank Plain of Assam. Research \& Reviews: Journal of Agricultural Science \& Technology 2(1):36-46.

- Peyvast G, Olfati JA, Madeni S, Forghani A (2008) Effect of vermicompost on the growth and yield of spinach (Spinacia oleracea.). Journal of Food, Agriculture \& Environment 6(1):110-113.

- Sabrina DT, Hanafi MM, Gandahi AW, Mohamed MTM, Aziz NAA (2013) Effect of mixed organic-inorganic fertilizer on growth and phosphorous uptake of setaria grass (Setaria splendida). Australian Journal of Crop Science 7(1):75-83.

- Scott, M. A., (1988). The use of worm-digested animal waste as a supplement to peat in loamless composts for hardy nursery stock. In Earthworms in Environmental and Waste.

- $\quad$ Siddagangaiah, B.A., M.R. Vadiraj, M.R. Sudharshan and V. Krishnakumar. (1996). Standardization of rooting media for propagation of vanilla (Vanilla planifoliaAndr.). Journal of Spices and Aromatic Crops, 5: 131-133. 
"Comparative Study of Soil Mixed vermicompost and Cattle Dung on the Growth Parameters of Triticum astivum (Wheat) and Faciolus mungo (Urad) Plant"

- Singh BK, Pathak KA, Verma AK, Verma VK, Deka BC (2011) Effects Of vermicompost, fertilizer and mulch On plant Growth, nodulation and pod yield of French bean (Phaseolus vulgaris L.). Vegetable Crops Research Bulletin 74(1):153-165.

- Singh R, Sharma RR, Kumar S, Gupta RK, Patil RT (2008) Vermicompost substitution influences growth, physiological disorders, fruit yield and quality of strawberry (Fragaria xananassaDuch.). BioresourTechnol 99:8507-8511.

- Suthar S (2009) Impact of vermicompost and composted farmyard manure on growth and yield of garlic (Allium stivum L.) field crop. International Journal of Plant Production 3(1):27-38.

- Suthar, S and. Singh, S.(2008) Vermicomposting of domestic waste by using two epigeic earthworms (Perionyx excavatus and Perionyx sansibaricus).Int. J. Environ. Sci. Tech. 5 (1): 99-106.

- Taleshi K, shokoh-far A, Rafiee M, Noormahamadi G, Sakinejhad T (2011) Effect of vermicompost and nitrogen levels on yield and yield component of safflower (Carthamus tinctorius L.) Under late season drought stress. International journal of Agronomy and Plant Production 2(1):15-22.

- Thankamani, C.K., K. Sivaraman and K. Kandiannan. (1996) Response of clove (Syzygium aromaticum (L.) Merr. \& Perry) seedlings and black pepper (Piper nigrumL.) cuttings to propagating media under nursery conditions. Journal of Spices and Aromatic Crops, 5: 99-104.

- Thanunathan, K., S. Natarajan, R. Senthilkumar and K. Arulmurugan. (1997) Effect of different sources of organic amendments on growth and yield of onion in mine spoil. Madras Agricultural Journal, 84: 382-384.

- Tomati, U., Galli, E., Grappelli, A. and Di Lena, G. (1990) Effect of Earthworm Casts on Protein Synthesis in Radish (Raphanussativum) and Lettuce (Lactucasativa) Seedlings. Biology and Fertility of Soils, 9, 288-289.

- Uma B, Malathi M (2009) Vermicompost as a soil supplement to improve growth and yield of Amaranthus species. Res J AgricBiolSci 5(6):1054-1060.

- Vadiraj, B.A. and Siddagangaiah, Potty, S.N. (1998) Response of coriander (Coriandrum sativum) cultivars to graded levels of vermicomposts. Journal of Spices and Aromatic Crops 7: 141-143.

- Vijaya KS, Seethalakshmi S (2011) Contribution of Parthenium vermicompost in altering growth, yield and quality of Alelmoschus esculentus Moench. Advanced Biotech 11(02):44-47.

- Wani, S.P. and K.K. Lee. Biofertilizers for sustaining cereal crop production. In: S. Kannaiyan (Ed.) Biotechnology of Biofertilizers, Narosha Publishing House, New Delhi, India. (2002).

- Wilson, D.P., Carlile, W.R., (1989) Plant growth in potting media containing worm-worked duck waste. Acta Horticulturae 238: 205-220.

Citation: Bhati Praveesh, Shouche Shobha, Jain Sudhir Kumar, Dhundhale Kavita, "Comparative Study of Soil Mixed vermicompost and Cattle Dung on the Growth Parameters of Triticum astivum (Wheat) and Faciolus mungo (Urad)Plant". American Research Journal of Agriculture, V3, I1; pp:1-14

Copyright (C) 2016 Bhati Praveesh, Shouche Shobha, Jain Sudhir Kumar, Dhundhale Kavita, This is an open access article distributed under the Creative Commons Attribution License, which permits unrestricted use, distribution, and reproduction in any medium, provided the original work is properly cited. 